\title{
ANALYSIS OF THE GENETIC DIVERSITY AND POPULATION STRUCTURE OF LATVIAN ASH (FRAXINUS EXCELSIOR L.) STANDS USING NUCLEAR AND CHLOROPLAST SSR MARKERS
}

\author{
Dainis Rungǵis”, Anna Korica, Agnese Gailīte, Ilze Pušpure, and Ilze Veinberga \\ Latvian State Forest Research Institute "Silava", Rīgas 111, Salapils, LV-2169, LATVIA \\ \# Corresponding author
}

Contributed by Dainis Rung̣is

\begin{abstract}
Common ash (Fraxinus excelsior L.) has a widespread distribution throughout Europe, and Latvia is almost at the north eastern edge of the distribution range. In Europe, ash is threatened by ash dieback, a disease caused by the introduced ascomycete Hymenoscyphus fraxineus. Chloroplast and nuclear DNA markers have been used to study the genetic diversity and population structure of ash both in a broader pan-European context as well as in more restricted regions. Some of the markers analysed in these previously published reports were also utilised in this study, enabling comparisons of the genetic parameters calculated from the nuclear SSR marker data and of the haplotypes identified with the chloroplast markers. Analysis of chloroplast markers revealed one dominant haplotype in Latvian stands, which corresponds to the haplotype previously found in Eastern Europe and Scandinavia. A second haplotype, corresponding to a previously reported central European haplotype was found in all individuals from the Kemeri stand, indicating that this stand was naturally established from introduced germplasm, which was planted in a neighbouring park. The nuclear SSR markers revealed low levels of differentiation of Latvian F. excelsior stands, probably due efficient pollen flow between stands. The analysis of both chloroplast and nuclear DNA markers has revealed different aspects of the structure and provenance of Latvian F. excelsior populations.
\end{abstract}

Key words: pollen flow, population differentiation, introduced germplasm, post-glacial migration.

\section{INTRODUCTION}

Common ash (Fraxinus excelsior L.) has a widespread distribution throughout Europe, with the exception of the central and southern parts of the Iberian Peninsula, south-east Turkey and northern Scandinavia (Dobrowolska et al., 2011, and references therein). Latvia is almost at the north eastern edge of the distribution range (Anonymous, 2009), and $F$. excelsior comprises approximately $0.5 \%$ (14 582 ha) of the total forested area (Anonymous, 2014). It is mainly found in mixed stands, together with other deciduous species: elm (Ulmus glabra Huds.), oak (Quercus robur L.), aspen (Populus tremula L.), birch (Betula pendula Roth.). In moist sites, it mostly occurs with black alder (Alnus glutinosa (L.) Gaertn.), as observed in other European countries (Anonymous, 2005; Dobrowolska et al., 2011). Ash grows on a wide range of site types but dominates mainly on fertile, biologically active, moist and seasonally excessively moist soil conditions (Laiviņš and Mangele, 2004; Anonymous, 2005). In Europe, ash is threatened by ash dieback, a disease caused by the introduced ascomycete Hymenoscyphus fraxineus. This fungus originates from East Asia, and was confirmed as the causal agent of European ash dieback in Poland in 2006 (Kowalski, 2006). Since the probable in- troduction of this fungus into Europe in the 1990s, it has spread throughout Europe, and is currently threatening common ash throughout most of its distributional range (Kowalski and Holdenrieder, 2009).

A limited number of nuclear microsatellite or simple sequence repeat (SSR) markers have been developed for $F$. excelsior (Brachet et al., 1999; Lefort et al., 1999), which have been used to study the genetic diversity and population structure of common ash both in a broader pan-European context as well as in more restricted regions. In addition, a set of conserved chloroplast SSR markers have been developed that have been applied to a wide range of angiosperm species (Weising et al., 1999). European F. excelsior populations have been investigated using nuclear SSR markers (Heuertz et al., 2004a) as well as chloroplast markers (Heuertz et al., 2004b). Nuclear SSRs have also been used to study ash populations in Bulgaria (Heuertz et al., 2001), France (Morand et al., 2002), Romania (Heuertz, 2003), Scotland (Bacles et al., 2005), Germany (Hebel et al., 2006), Italy (Ferrazzini et al., 2007) and Bosnia and Herzegovina (Ballian et al., 2008). In many of these studies, the DNA markers utilised are at least partially overlapping, enabling direct comparisons of the genetic parameters calcu- 
lated from the nuclear SSR marker data and the haplotypes identified with the chloroplast markers.

Analysis of the European populations of $F$. excelsior using chloroplast DNA markers suggest post-glacial recolonization of Europe from refugia located in Iberia, Italy, the Alps and the Balkan Peninsula, as suggested by the allelic richness in these southern populations. In addition, strong signatures of the post-glacial migration routes remained in the current northern European populations, which showed high levels of differentiation of chloroplast haplotypes, indicating only a small overlap of recolonising maternal lineages (Heuertz et al., 2004b). In contrast, analysis of European populations of $F$. excelsior with nuclear SSR markers revealed very little differentiation of populations ranging from the British Isles over central Europe to Lithuania and Latvia (Heuertz et al., 2004a). The discrepancy between the high levels of population differentiation identified by the chloroplast analyses, and the low levels revealed by nuclear SSR marker analyses has been suggested to be due to efficient postglacial pollen flow (Heuertz et al., 2004b).

Smaller scale analyses of $F$. excelsior populations using nuclear SSR markers have revealed patterns of genetic diversity and population differentiation which are in agreement with the pan-European studies. In general, southern populations have high genetic diversity (e.g Heuertz et al., 2001; Ferrazzini et al., 2007; Ballian et al., 2008), while the northern populations have lower levels of genetic diversity (Bacles et al., 2005). The previous studies also reported low levels of population differentiation, even between fragmented populations at the northern boundary of the distribution range of $F$. excelsior (Bacles et al., 2005). In addition, many of the previous studies reported high inbreeding coefficients (Fis) detected with the nuclear SSR markers (e.g. Bacles et al., 2005; Ferrazzini et al., 2007; Ballian et al., 2008). These increased Fis values could be due to biological factors and population structure (i.e. assortative mating or a Wahlund effect) or to the presence of null alleles. Null alleles are caused by mutations leading to the non-amplification of specific alleles by PCR, leading to an apparent excess of homozygosity. This can have an influence on the estimation of population genetic parameters (Chapuis and Estoup, 2007). However, five nuclear SSR markers (M2-30, Femsat14, Femsat15, Femsatl11, Femsat119) were used to genotype the progeny of controlled (test) crosses, which allows the Mendelian segregation of alleles to be observed, thus enabling detection of null alleles. Potential null alleles were only detected at one locus (Femsat15), with the other loci conforming to the expected segregation ratios (Morand et al., 2002). In addition, the Fis values were not significantly positive in all studies utilising these nuclear SSR markers (e.g. Heuertz et al., 2003), and therefore the high inbreeding coefficients are probably due to biological factors and/or structure within the previously analysed $F$. excelsior populations.

The aim of this study was to initiate a survey of the genetic diversity and population structure of ash (Fraxinus excelsior L.) in Latvia. Knowledge of the distribution of genetic di- versity within and between populations is required for optimal management of forest genetic resources. In addition, the analysis of haplotypes using chloroplast markers enables the post glacial recolonisation pathways to be determined and also the identification of possible introductions of germplasm. The results obtained from this study will form a basis for further studies of $F$. excelsior in Latvia, and allow comparison of the obtained results with previously published studies of $F$. excelsior populations in other European regions.

\section{MATERIALS AND METHODS}

Six nuclear and six chloroplast SSR markers were utilised to analyse 16 naturally regenerated ash stands located throughout the territory of Latvia. The markers utilised in this study were also utilised in previous studies of European F. excelsior populations, thus enabling comparisons of genetic diversity with these previously obtained results. Leaves were collected from approximately 24 young ash individuals (1-2 metres in height) from 16 naturally regenerated Fraxinus excelsior stands (Fig. 1, Table 1). The 'Skrīveri' and 'Bērvircava' stands have been designated as F. excelsior genetic resource stands. A total of 372 Fraxinus excelsior individuals were analysed with the nuclear and chloroplast SSR markers.

DNA from leaves was isolated using a CTAB-based method (Porebski et al., 1997). Genotyping was done using six nuclear SSR markers - Femsat14, Femsat110, Femsat111, Femsatl16, Femsat119 (Lefort et al. 1999) and M2-30 (Brachet et al. 1999) and six angiosperm chloroplast markers ccmp2, ccmp 4, ccmp6, ccmp10, ccmp7 and ccmp3 (Weising et al., 1999). Each forward primer was labelled with a different fluorophore (6-FAM, HEX or TMR) to facilitate visualisation using capillary electrophoresis. The PCR reactions for the nuclear SSR markers were carried out in a $20 \mu \mathrm{l}$ solution containing, $0.2 \mathrm{mM}$ dNTPs, $2.5 \mathrm{mM}$ $\mathrm{MgCl}_{2}, 1.5 \mu \mathrm{l}$ DNA solution, $1 \mathrm{x}$ Taq buffer and $1 \mathrm{U}$ of recombinant Taq DNA polymerase (Thermo Scientific). PCR cycling conditions consisted of an initial denaturation step of $95^{\circ} \mathrm{C}$ for $4 \mathrm{~min} ; 35$ cycles of $94{ }^{\circ} \mathrm{C}$ for $30 \mathrm{~s}, 52{ }^{\circ} \mathrm{C}$ for 45 $\mathrm{s}\left(56^{\circ} \mathrm{C}\right.$ for $\left.\mathrm{M} 2-30\right)$, and $72{ }^{\circ} \mathrm{C}$ for $60 \mathrm{~s}$; followed by a final extension step of $72{ }^{\circ} \mathrm{C}$ for $10 \mathrm{~min}$. The PCR reactions for

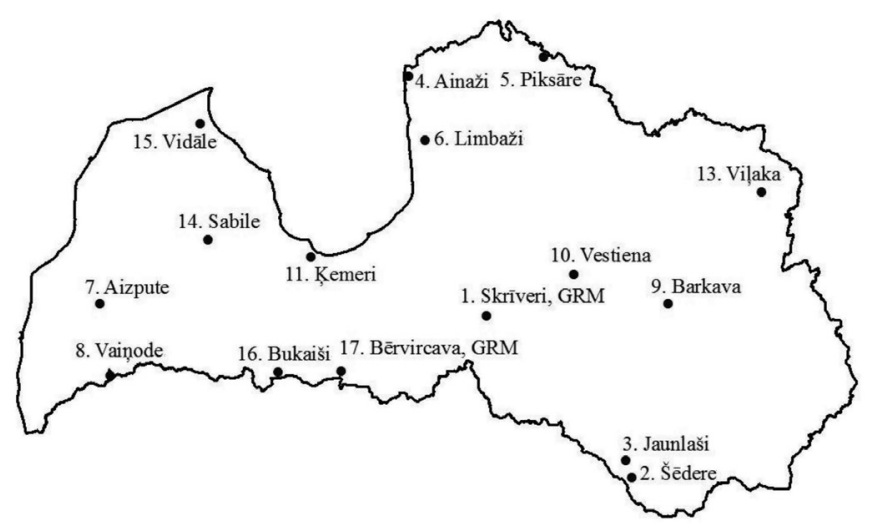

Fig. 1. Location of the sampled Latvian Fraxinus excelsior stands. 
Table 1

COORDINATES AND ELEVATION OF THE SAMPLED LATVIAN FRAXINUS EXCELSIOR STANDS

\begin{tabular}{|c|c|c|c|c|}
\hline \multirow[t]{2}{*}{ Region } & \multirow[t]{2}{*}{ Stand } & \multicolumn{2}{|c|}{ Coordinates } & \multirow{2}{*}{$\begin{array}{l}\text { Elevation } \\
\text { (m above } \\
\text { sea level) }\end{array}$} \\
\hline & & $X$ & $\mathrm{Y}$ & \\
\hline \multirow[t]{3}{*}{ Coastal lowland } & 4. Ainaži & 523032 & 6409092 & 9 \\
\hline & 15. Vidāle & 411202 & 6383595 & 24 \\
\hline & 11. Kemeri & 470181 & 6312350 & 8 \\
\hline \multirow[t]{3}{*}{ Western Kurzeme } & 7. Aizpute & 357289 & 6287409 & 75 \\
\hline & 14. Sabile & 415074 & 6321517 & 80 \\
\hline & 8. Vaingode & 362909 & 6248835 & 110 \\
\hline \multirow[t]{2}{*}{ Western Zemgale } & 17. Bērvircava & 486569 & 6251149 & 34 \\
\hline & 16. Bukaiši & 452675 & 6250481 & 66 \\
\hline \multirow[t]{2}{*}{ Augšzeme } & 3. Jaunlaši & 639266 & 6203264 & 130 \\
\hline & 2. Šēdere & 642444 & 6194070 & 171 \\
\hline \multirow[t]{2}{*}{ Northern Vidzeme } & 6. Limbaži & 531633 & 6375057 & 52 \\
\hline & 5. Piksāre & 595114 & 6419336 & 96 \\
\hline Southern Vidzeme & 1. Skrīveri & 564760 & 6280660 & 90 \\
\hline Vidzeme highlands & 10. Vestiena & 611348 & 6302999 & 202 \\
\hline \multirow[t]{2}{*}{ Aiviekste } & 9. Barkava & 661933 & 6287151 & 94 \\
\hline & 13. Viliaka & 712240 & 6346960 & 122 \\
\hline
\end{tabular}

the chloroplast SSR were similar, but with the addition of a final concentration of $1 \% \mathrm{BSA}$ to the reaction. The PCR profile consisted of an initial denaturation at $96{ }^{\circ} \mathrm{C}$ for 5 min followed by 25 cycles of denaturation at $94{ }^{\circ} \mathrm{C}$ for $60 \mathrm{~s}$, annealing at $55^{\circ} \mathrm{C}$ for $60 \mathrm{~s}$, and extension at $72{ }^{\circ} \mathrm{C}$ for $60 \mathrm{~s}$. Final extension of amplified DNA occurred at $72{ }^{\circ} \mathrm{C}$ for 10 min. All PCR reactions were carried out in an Eppendorf Mastercycler ep gradient thermal cycler. Amplification fragments were separated on an ABI Prism 3130xl Genetic Analyzer (Applied Biosystems) and visualised with GeneMapper 3.5.

The chloroplast marker data was combined into haplotypes. Analysis of nuclear SSR data was done using Fstat version 2.9.3.2 (Goudet, 2001) and GenAlEx 6.5 (Peakall and Smouse, 2012). Dendrograms were constructed using the software MEGA 5.2 (Tamura et al., 2011). A Bayesian clustering approach, implemented using the software STRUCTURE version 2.1 (Pritchard et al., 2000), was used to estimate the most likely number of clusters $(\mathrm{K})$ into which the nSSR genotypes were assigned with certain likelihood. The population priors were not used, and a burn-in period of 50000 iterations followed by 50000 iterations was used. K was set from 1 to 16 , and each run was replicated 20 times. The most likely number of clusters was identified by the delta K criterion (Evanno et al., 2005) with the STRUCTURE HARVESTER Web version 0.6.93 software (Earl and vonHoldt, 2012).

\section{RESULTS}

Of the six analysed chloroplast SSR markers, only three were polymorphic (ccmp6, ccmp7, ccmp10). The genotypes of these three loci were combined into two haplotypes, of which one was found in all individuals from all stands except for the 'Kemeri' stand, where all individuals had the second identified haplotype. While the sizes of all the chloroplast alleles amplified in this study were not identical to the values reported previously, it was possible to unambiguously match the identified haplotypes to previously reported European $F$. excelsior haplotypes (Heuertz et al., 2004b). The most common haplotype in this study, which was found in all stands except 'Kemeri' was the haplotype H01, which is widespread in Eastern Europe and Scandinavia. The allele sizes for this haplotype were as follows (with the previously reported sizes in brackets): ccmp6 - 97 (97); ccmp7 - 115 (118); ccmp10 - 104 (103). The haplotype found exclusively in the 'Kemeri' stand corresponds to $\mathrm{H} 02$, which is the most common haplotype found in central Europe. The allele sizes for this haplotype were as follows (with the previously reported sizes in brackets): ccmp6 - 99 (99); ccmp7 - 114 (117); ccmp10 - 105 (104). The H01 and $\mathrm{H} 02$ alleles were the most common alleles in European $F$. excelsior populations, together representing $68 \%$ of the analysed individuals (Heuertz et al., 2004b). In addition, the other previously reported haplotypes were able to be excluded from comparisons with the results from this study, given the size differences of the polymorphic alleles. The differences in allele sizing are probably due to the use of differing genotyping platforms, protocols and reagents (Pasqualotto et al., 2007).

The total number of alleles identified by each nuclear SSR markers ranged from 10 (Femsat116) to 37 (M2-30) (mean 23.17 alleles). The number of effective alleles was considerably lower, ranging from 1.96 (Femsatl16) to 20.88 (M2-30) (mean 9.55 alleles), indicating the high proportion of low frequency alleles. The expected heterozygosity ranged from 0.49 (Femsatl16) to 0.95 (M2-30) (mean 0.82), while the observed heterozygosity was lower, ranging from 0.37 (Femsatl16) to 0.85 (Femsat119) (mean 0.64). As a result, the fixation index $(\mathrm{F})$ was positive for all loci, ranging from 0.06 (Femsat119) to 0.43 (Femsatl4) (mean 0.23). These were all significantly higher than zero, with the exception of the locus Femsatl19 ( $p<0.001)$ (Table 2).

The mean number of alleles found in each population over all the analysed nuclear SSR loci was similar, ranging from

Table 2

GENETIC DIVERSITY STATISTICS OF THE ANALYSED NUCLEAR SSR MARKERS

\begin{tabular}{l|c|c|c|c|c|c}
\hline \multicolumn{1}{c|}{ Locus } & $\mathrm{N}$ & $\mathrm{Na}$ & $\mathrm{Ne}$ & $\mathrm{Ho}$ & $\mathrm{He}$ & $\mathrm{F}$ \\
\hline Femsat14 & 364 & 23 & 5.23 & 0.46 & 0.81 & 0.43 \\
Femsat110 & 348 & 33 & 11.68 & 0.54 & 0.91 & 0.41 \\
Femsat111 & 370 & 16 & 6.79 & 0.78 & 0.85 & 0.09 \\
Femsat116 & 369 & 10 & 1.96 & 0.37 & 0.49 & 0.25 \\
Femsat119 & 368 & 20 & 10.77 & 0.85 & 0.91 & 0.06 \\
M2-30 & 363 & 37 & 20.88 & 0.83 & 0.95 & 0.12
\end{tabular}

$\mathrm{N}$ - number of individuals, $\mathrm{Na}$ - number of alleles, $\mathrm{Ne}$ - number of effective alleles, Ho - observed heterozygosity, He - expected heterozygosity, F - inbreeding coefficient. 
GENETIC DIVERSITY STATISTICS OF THE ANALYSED LATVIAN $F$. EXCELSIOR STANDS

\begin{tabular}{|c|c|c|c|c|c|c|c|c|c|c|c|c|c|c|c|c|c|}
\hline Population & Skrīveri & Šēdere & $\begin{array}{c}\text { Jaun- } \\
\text { laši }\end{array}$ & Ainaži & Piksāre & $\begin{array}{c}\text { Limba- } \\
\text { ži }\end{array}$ & Aizpute & $\begin{array}{c}\text { Vaino- } \\
\text { de }\end{array}$ & $\begin{array}{c}\text { Barka- } \\
\text { va }\end{array}$ & $\begin{array}{c}\text { Vestie- } \\
\text { na }\end{array}$ & Kemeri & Viḷaka & Abava & Vidāle & Bukaiši & $\begin{array}{c}\text { Bērvir- } \\
\text { cava }\end{array}$ & Mean \\
\hline $\mathrm{Na}$ & 12.33 & 10.67 & 11.00 & 10.17 & 10.50 & 11.17 & 12.00 & 9.00 & 11.83 & 9.83 & 10.50 & 8.17 & 11.00 & 11.83 & 11.00 & 11.33 & 10.77 \\
\hline $\begin{array}{l}\mathrm{Na} \text { (freq. } \geq \\
0.05)\end{array}$ & 5.33 & 5.67 & 4.67 & 6.33 & 5.33 & 5.50 & 6.67 & 4.50 & 4.83 & 5.00 & 5.00 & 4.50 & 4.50 & 6.17 & 5.33 & 5.67 & 5.31 \\
\hline $\mathrm{Ne}$ & 7.32 & 5.71 & 5.91 & 6.85 & 5.57 & 6.57 & 8.28 & 4.72 & 6.38 & 5.08 & 6.04 & 4.00 & 5.84 & 7.07 & 6.95 & 7.11 & 6.21 \\
\hline $\begin{array}{l}\text { No. of pri- } \\
\text { vate alleles }\end{array}$ & 0.33 & 0.67 & 0.33 & 0.00 & 0.17 & 0.33 & 0.17 & 0.17 & 0.00 & 0.00 & 0.00 & 0.00 & 0.00 & 0.17 & 0.00 & 0.00 & 0.15 \\
\hline $\mathrm{He}$ & 0.80 & 0.76 & 0.75 & 0.77 & 0.77 & 0.76 & 0.82 & 0.74 & 0.77 & 0.73 & 0.78 & 0.67 & 0.76 & 0.78 & 0.80 & 0.83 & 0.77 \\
\hline
\end{tabular}

$\mathrm{Na}$ - number of alleles, $\mathrm{Ne}$ - number of effective alleles, $\mathrm{He}$ - expected heterozygosity.

8.17 (Vilaka) to 12.33 (Skrīveri) (mean 10.77). The number of alleles with a frequency of over 0.05 was also similar, ranging from 4.50 (Vainode) to 6.67 (Aizpute) (mean 5.31). A small number of private or unique alleles (found in only one stand) were only found in eight stands (Skrīveri, Šēdere, Jaunlaši, Piksāre, Limbaži, Aizpute, Vaiṇode, Vidāle) (ranging from a mean over all loci of 0.17-0.67 alleles) (Table 3 ). A total of 14 private alleles were identified with five nuclear SSR markers (Femsatl4, Femsatl10, Femsat116, Femsat119, M2-30), of which only three had a frequency above 0.05 in their respective stand (Table 4).

The level of population differentiation detected by the analysed nuclear SSR markers was low, but significant (Fst = $0.045, \mathrm{p}<0.001$ ), as calculated by AMOVA (999 permutations). The maximum pairwise population Fst value was 0.151 between Vainode and Vilaka, and these two stands were the most differentiated from each other and also from the other analysed stands. The pairwise Fst are shown in Table 5. The most genetically differentiated stands are Viliaka, Šēdere, Vestiena and Vaingode, with pairwise Fst values above 0.05 . These stands were also differentiated from each other, with all pairwise Fst values between these four stands being higher than 0.075 .

The pairwise Nei genetic distances between stands ranged from 0.10 (Jaunlaši-Ainaži) to 0.75 (Vainode-Vilaka) (mean 0.28). The pairwise Nei genetic distances were used to construct a neighbour-joining dendrogram (Fig. 2). As can be seen from the branch lengths, the most differentiated stands were Vilaka, Vainode, Vestiena and Šēdere, as previously shown by the pairwise Fst results. The clustering of the populations did not show any geographical or other structure, which was expected due to the low level of population differentiation as previously reported by the AMOVA.

The Bayesian clustering approach, implemented using the software STRUCTURE version 2.1, identified that the most likely number of clusters was three (Fig. 3). However, there were additional peaks in the delta $\mathrm{K}$ plot corresponding to a larger number of clusters. These clusters did not correspond to any geographic grouping, and differentiated individual stands with a higher proportion of membership of a particular cluster. In the case of three clusters, three stands (Šèdere, Limbaži, Vestiena) had a relatively high proportion (over
Table 4

FREQUENCY OF PRIVATE ALLELES ACROSS LOCI

\begin{tabular}{llccc}
\hline \multicolumn{1}{c|}{ Population } & \multicolumn{1}{c|}{ Locus } & Allele size (bp) & Frequency \\
\hline Skrīveri & Femsatl4 & 208 & 0.042 \\
Skrīveri & M2-30 & 210 & 0.021 \\
Šēdere & Femsatl4 & 210 & 0.042 \\
Šēdere & Femsatl10 & 261 & 0.021 \\
Šēdere & Femsatl16 & 173 & 0.063 \\
Šēdere & M2-30 & 188 & 0.021 \\
Jaunlaši & Femsatl19 & 165 & 0.021 \\
Jaunlaši & M2-30 & 267 & 0.021 \\
Piksāre & Femsatl10 & 161 & 0.043 \\
Limbaži & Femsatl10 & 267 & 0.042 \\
Limbaži & Femsatl16 & 185 & 0.063 \\
Aizpute & Femsatl16 & 194 & 0.100 \\
Vain̄ode & M2-30 & 225 & 0.022 \\
Vidāle & Femsatl16 & 204 & 0.021 \\
bp - base pairs. & & &
\end{tabular}

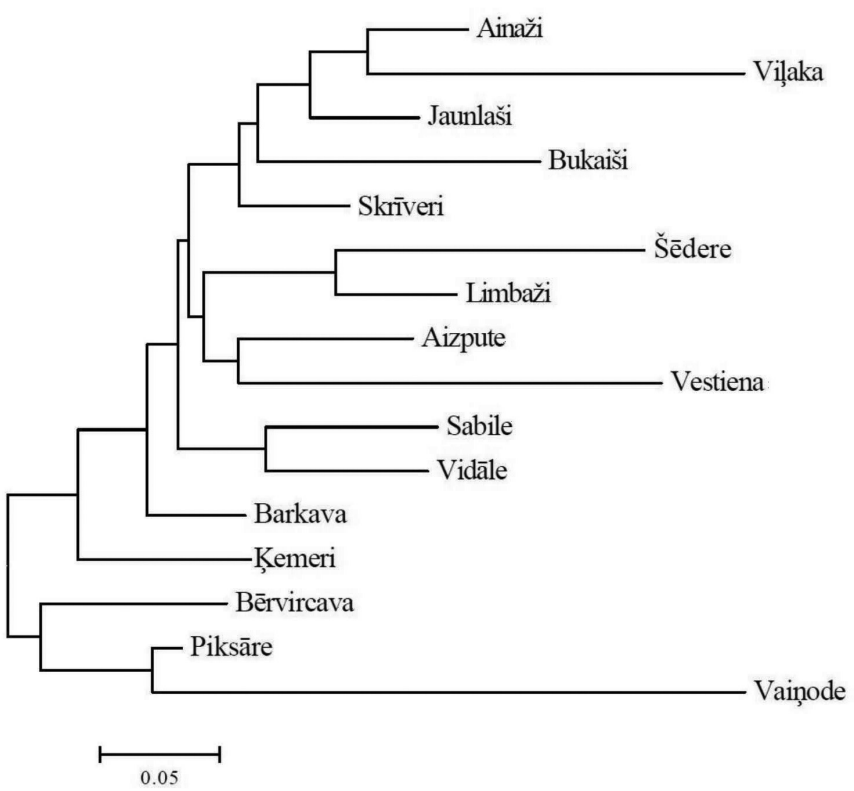

Fig. 2. Neighbour-joining dendrogram of pairwise Nei genetic distances between the analysed Latvian $F$. excelsior stands. 
PAIRWISE FST VALUES BETWEEN ANALYSED F. EXCELSIOR STANDS

\begin{tabular}{|c|c|c|c|c|c|c|c|c|c|c|c|c|c|c|c|c|}
\hline Skrīveri & Šēdere & Jaunlaši & Ainaži & Piksāre & Limbaži & Aizpute & Vain,ode & Barkava & $\begin{array}{c}\text { Vestie- } \\
\text { na }\end{array}$ & Kemeri & Vilaka & Abava & Vidāle & Bukaiši & $\begin{array}{c}\text { Bērvir- } \\
\text { cava }\end{array}$ & \\
\hline & 0.001 & 0.026 & 0.290 & 0.002 & 0.001 & 0.001 & 0.001 & 0.062 & 0.001 & 0.005 & 0.001 & 0.002 & 0.006 & 0.009 & 0.004 & Skrīveri \\
\hline 0.030 & & 0.001 & 0.001 & 0.001 & 0.001 & 0.001 & 0.001 & 0.001 & 0.001 & 0.001 & 0.001 & 0.001 & 0.001 & 0.001 & 0.001 & Šēdere \\
\hline 0.012 & 0.056 & & 0.454 & 0.002 & 0.001 & 0.001 & 0.001 & 0.004 & 0.001 & 0.014 & 0.001 & 0.001 & 0.001 & 0.001 & 0.001 & Jaunlaši \\
\hline 0.002 & 0.050 & 0.000 & & 0.002 & 0.002 & 0.001 & 0.001 & 0.039 & 0.001 & 0.034 & 0.001 & 0.001 & 0.001 & 0.002 & 0.003 & Ainaži \\
\hline 0.026 & 0.047 & 0.028 & 0.031 & & 0.001 & 0.001 & 0.001 & 0.004 & 0.001 & 0.004 & 0.001 & 0.001 & 0.001 & 0.001 & 0.005 & Piksāre \\
\hline 0.021 & 0.028 & 0.042 & 0.024 & 0.042 & & 0.001 & 0.001 & 0.001 & 0.001 & 0.001 & 0.001 & 0.001 & 0.001 & 0.001 & 0.001 & Limbaži \\
\hline 0.024 & 0.057 & 0.048 & 0.034 & 0.047 & 0.049 & & 0.001 & 0.001 & 0.001 & 0.001 & 0.001 & 0.001 & 0.002 & 0.001 & 0.001 & Aizpute \\
\hline 0.072 & 0.109 & 0.084 & 0.075 & 0.045 & 0.106 & 0.086 & & 0.001 & 0.001 & 0.001 & 0.001 & 0.001 & 0.001 & 0.001 & 0.001 & Vainode \\
\hline 0.009 & 0.035 & 0.020 & 0.012 & 0.019 & 0.022 & 0.023 & 0.067 & & 0.001 & 0.014 & 0.001 & 0.003 & 0.001 & 0.001 & 0.005 & Barkava \\
\hline 0.017 & 0.052 & 0.015 & 0.013 & 0.020 & 0.030 & 0.038 & 0.061 & 0.015 & 0.049 & & 0.001 & 0.001 & 0.001 & 0.001 & 0.001 & Ķemeri \\
\hline 0.045 & 0.091 & 0.054 & 0.035 & 0.091 & 0.063 & 0.063 & 0.151 & 0.058 & 0.107 & 0.076 & & 0.001 & 0.001 & 0.001 & 0.001 & Viḷaka \\
\hline 0.020 & 0.057 & 0.028 & 0.033 & 0.039 & 0.041 & 0.038 & 0.090 & 0.019 & 0.066 & 0.037 & 0.072 & & 0.025 & 0.001 & 0.006 & Abava \\
\hline 0.014 & 0.050 & 0.036 & 0.031 & 0.034 & 0.027 & 0.027 & 0.084 & 0.019 & 0.054 & 0.032 & 0.067 & 0.011 & & 0.001 & 0.001 & Vidāle \\
\hline 0.013 & 0.049 & 0.024 & 0.021 & 0.031 & 0.048 & 0.039 & 0.082 & 0.032 & 0.059 & 0.026 & 0.069 & 0.029 & 0.040 & & 0.001 & Bukaiši \\
\hline 0.017 & 0.059 & 0.031 & 0.031 & 0.020 & 0.049 & 0.024 & 0.045 & 0.016 & 0.061 & 0.022 & 0.074 & 0.020 & 0.025 & 0.028 & & $\begin{array}{c}\text { Bērvir- } \\
\text { cava }\end{array}$ \\
\hline
\end{tabular}

Fst values below diagonal, probability $\mathrm{P}$ (rand >= data) based on 999 permutations above diagonal. Pairwise Fst values $\geq 0.05$ are highlighted.

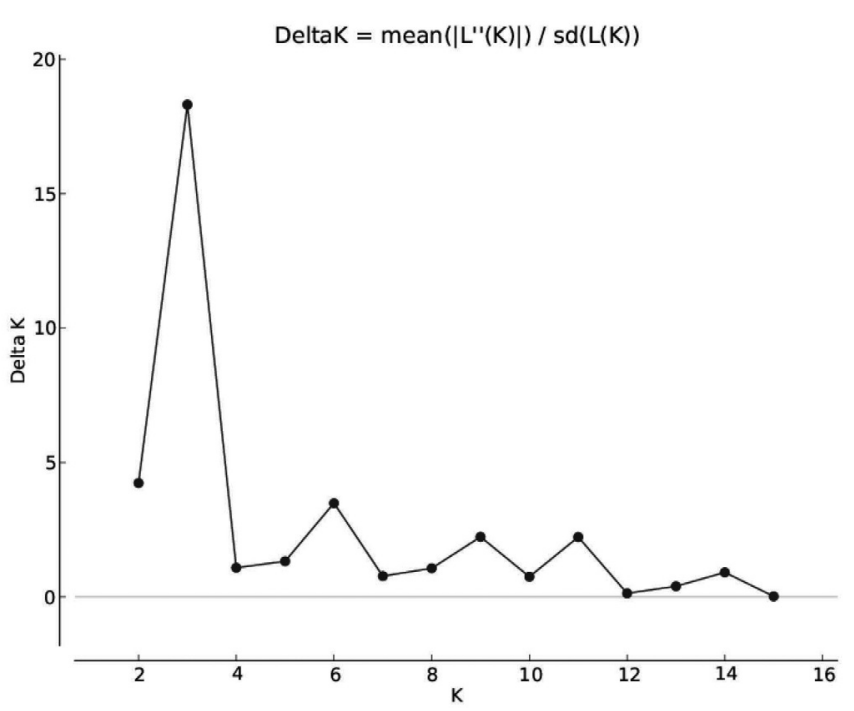

Fig. 3. Plot of delta $\mathrm{K}$ (the second order rate of change of the likelihood function with respect to $\mathrm{K}$ ) vs. $\mathrm{K}$ (predefined number of clusters). The mode of delta $\mathrm{K}$ at $\mathrm{K}=3$ indicates the most probable number of clusters (3) in the analysed Latvian F. excelsior individuals.

0.6) of individuals assigned to one cluster; while the Vain,ode and Vil̨aka stands had a high proportion (over 0.7 ) of individuals assigned to each of the other two clusters. The remaining stands had an approximately equal proportion of individuals assigned to each of the three clusters (data not shown).

\section{DISCUSSION}

The chloroplast DNA markers identified one stand (Kemeri), where all analysed individuals had the haplotype $\mathrm{H} 02$, in contrast to the common haplotype $\mathrm{H} 01$ found in all other stands and individuals. The H02 haplotype is common in central Europe, and the closest previously identified natural $F$. excelsior stands with this haplotype were in Poland (Heuertz et al., 2004b). The individuals that were sampled were young, naturally regenerated individuals, and the Kemeri stand from which they were collected did not show any signs of being artificially established. Given the uniform presence of this haplotype within the Kemeri stand, and the complete absence of it in the other analysed populations, it seems likely that this stand has been established by ash individuals that have escaped from nearby parks or other artificial plantings, where genotypes from central Europe may have been introduced. The Kemeri stand is adjacent to the Kemeri sanatorium, which has been in operation since 1796 (Kupcis, Libietis, 1933/34). In the period between 1839 and 1846, the nursery owner C. H. Wagner established a park adjoining the sanatorium (Dambis et al., 2007), planting material (including $F$. excelsior) obtained from commercial nurseries, the majority of which was sourced from Western Europe (Zigra, 1805; Wagner, 1822). This stand and surrounding stands should be examined in more detail, including sampling mature individuals, to determine the extent of this haplotype in this area. In addition, 
COMPARISON OF ALLELE NUMBER AND INBREEDING COEFFICIENTS

\begin{tabular}{|c|c|c|c|c|c|c|c|c|c|c|c|c|c|c|}
\hline \multirow[b]{2}{*}{ Locus } & \multicolumn{2}{|c|}{ Latvia $^{1}$} & \multicolumn{2}{|c|}{ Scotland $^{2}$} & \multicolumn{2}{|c|}{ France $^{3}$} & \multicolumn{2}{|c|}{ Italy $^{4}$} & \multicolumn{2}{|c|}{ Bulgaria $^{5}$} & \multicolumn{2}{|c|}{$\begin{array}{c}\text { Bosnia and } \\
\text { Herzegovina }^{6}\end{array}$} & \multicolumn{2}{|c|}{ Romania $^{7}$} \\
\hline & $\mathrm{Na}$ & $\mathrm{F}$ & $\mathrm{Na}$ & $\mathrm{F}$ & $\mathrm{Na}$ & $\mathrm{F}$ & $\mathrm{Na}$ & $\mathrm{F}$ & $\mathrm{Na}$ & $\mathrm{F}$ & $\mathrm{Na}$ & $\mathrm{F}$ & $\mathrm{Na}$ & $\mathrm{F}$ \\
\hline Femsatl4 & 25 & 0.455 & nd & nd & 37 & 0.102 & 32 & 0.274 & 50 & 0.081 & 20 & 0.393 & 37 & 0.007 \\
\hline Femsatl10 & 34 & 0.421 & nd & nd & nd & nd & 76 & 0.332 & nd & nd & 55 & 0.371 & nd & nd \\
\hline Femsatl11 & 17 & 0.088 & nd & nd & 40 & 0.033 & 42 & 0.312 & 32 & 0.080 & 24 & 0.328 & 32 & 0.003 \\
\hline Femsatl16 & 10 & 0.274 & 6 & 0.032 & nd & nd & 9 & 0.191 & 10 & 0.124 & 12 & 0.156 & 10 & 0.165 \\
\hline Femsat119 & 21 & 0.075 & 19 & 0.334 & 36 & 0.130 & 55 & 0.078 & 33 & 0.133 & 26 & 0.167 & 27 & -0.07 \\
\hline M2-30 & 37 & 0.136 & 30 & 0.191 & 56 & 0.161 & nd & nd & 59 & 0.114 & nd & nd & 42 & 0.043 \\
\hline
\end{tabular}

$\mathrm{Na}$ - number of alleles, F- inbreeding coefficient, nd - no data. 1 - this study, 2 - Bacles et al., 2005, 3 - Morand et al., 2002, 4 - Ferrazzini et al., 2007, 5 - Heuertz et al., 2001, 6 - Ballian et al., 2008, 7 - Heuertz et al., 2003.

a survey of the known artificial plantings within the area would enable comparison to the naturally regenerated stands in order to determine any genetic relationships between them. Interestingly, analysis of the nuclear SSR marker results did not differentiate the Kemeri stand from the other analysed stands. This is probably due to the efficiency of pollen flow over larger distances, which would reduce the differentiation of the naturally regenerated individual that were descended from the artificially introduced genotypes, while maintaining the maternally inherited chloroplast haplotype. Analysis of older individuals may enable a higher level of differentiation from other Latvian $F$. excelsior stands to be identified with the nuclear SSR markers, however, given that these artificial introductions have been occurring since the early $19^{\text {th }}$ century, the original founder genotypes may not be present in this area, and only the chloroplast haplotype persists. In addition, populations from central Europe could be analysed with the chloroplast and nuclear markers in conjunction with the Latvian samples. This would enable a direct comparison of the obtained haplotypes, and to determine the level of differentiation identified with the nuclear markers between Latvian and central European ash populations.

The genetic diversity identified by the nuclear SSR markers utilised in this study was lower than identified in more southern populations in previous studies (Table 6). At almost all loci that were also analysed in previous studies, the number of alleles was higher in previous studies, with the exception of Scotland, where the number of alleles was consistently lower. This is in agreement with the post-glacial expansion of $F$. excelsior from southern refugia, with populations at the northernmost edge having a lower level of genetic diversity. However, the inbreeding coefficients were significantly positive for most of the loci/studies, with the exception of Romania, indicating that this could be a feature of $F$. excelsior stands, regardless of their location within the distribution areal. This could be related to the mating system of F. excelsior, which is polygamous, with a continuum between pure male and pure female individuals with hermaphroditic intermediates (Wallander, 2008), or to other population structure processes.
The overall level of genetic differentiation identified with the nuclear SSR markers between the analysed Latvian stands was low, which is in agreement with previous pan-European studies, which found little differentiation of $F$. excelsior populations stretching from the British Isles over central Europe to Lithuania and Latvia (Heuertz et al., 2004a). Four of the Latvian F. excelsior stands were slightly more differentiated (Viḷaka, Šēdere, Vestiena, Vain,ode). These were not geographically clustered; however, it is interesting to note that all of these stands had an elevation above sea level of over $100 \mathrm{~m}$. The remaining stands were all located at an elevation of less than $100 \mathrm{~m}$ above sea level, with the exception of the Jaunlaši stand, which had an elevation of $130 \mathrm{~m}$ above sea level. The Jaunlaši stand was geographically close to the Šêdere stand (Fig. 1); however they were not clustered together in the neighbour-joining dendrogram and the difference in elevation between the two stands was $41 \mathrm{~m}$. One possibility is that the flowering time of the stands with a higher elevation is altered in comparison to the other stands, thus reducing the amount of gene flow between these stands and those at a lower elevation. Each of the elevated stands is geographically separated from each other as well, also decreasing the level of gene flow between the elevated stands, as demonstrated by the pairwise differentiation between the elevated stands as well as between the stands with a higher elevation and the stands with a lower elevation. The phenology of these stands should be further investigated to determine the extent of the role of flowering time in the differentiation of these stands, or if there are other possible factors influencing the population structure of Latvian $F$. excelsior stands.

The health status with regard to $H$. fraxineus, the causal pathogen of ash dieback, was assessed for a subset of the analysed $F$. excelsior populations (I. Pušpure, unpublished results). This revealed that the lowland coastal stands had the least favourable health status in comparison to the Eastern stands, which could be a result of more favourable environmental conditions for the pathogen. There was no discernible correlation of genetic population structure identified in this study with health status. Pliūra et al. (2011) found significant population differences with regard 
to resistance to $H$. fraxineus in Lithuania. However, these results were obtained from progeny trials in three locations. Therefore, the resistance status of Latvian F. excelsior populations should be assessed in a common environment, and the results of this study could be used as guide for the selection of the most genetically diverged populations for inclusion into future $F$. excelsior progeny trials, as well as the designation of additional genetic resource stands.

\section{CONCLUSIONS}

Analysis of chloroplast markers revealed only one dominant haplotype in Latvian stands, which corresponds to the haplotype previously found in Eastern Europe and Scandinavia. In addition, the central European haplotype was found in all individuals from the Kemeri stand, indicating that this stand has originated from introduced germplasm. The lack of differentiation by the nuclear SSR markers of the Kemeri stand from the other analysed stands indicates efficient pollen flow and the natural regeneration of the stand over several generations since the initial introduction. The nuclear SSR markers revealed low levels of differentiation of Latvian $F$. excelsior stands, again, probably due the efficient pollen flow. The slightly higher differentiation of stand found at a higher elevation above sea level could be due to phenological differences, however further investigation is required to elucidate this. The analysis of both chloroplast and nuclear DNA markers revealed different aspects of the structure and provenence of Latvian F. excelsior populations.

\section{ACKNOWLEDGEMENTS}

The study was funded by the joint stock company "Latvijas Valsts Meži" project "Ash forest destruction and regeneration in Latvia” (5.5.-5.1_0017_101_14_28) and by the Forest Sector Competence Centre project "Ecological risks of forest capital management- evaluation methods and recommendations for risk mitigation" (No L-KC-11-0004).

\section{REFERENCES}

Anonymous (2005). Fraxigen. Ash Species in Europe: Biological Characteristics and Practical Guidelines for Sustainable Use. University of Oxford, Oxford. $128 \mathrm{pp}$.

Anonymous (2009). EUFORGEN. Distribution maps, Fraxinus excelsior L. Available at: http://www.euforgen.org/fileadmin/www.euforgen.org/Documents/Maps/PDF/ Fraxinus_excelsior.pdf (accessed 22 December 2015).

Anonymous (2014). State Forest Service. Forest Statistics 2014 (MS Excel spreadsheets), CD ROM.

Bacles, C. F., Burczyk, J., Lowe, A. J., Ennos, R. A. (2005). Historical and contemporary mating patterns in remnant populations of the forest tree Fraxinus excelsior L. Evolution, 59 (5), 979-990.

Ballian, D., Monteleone, I., Ferrazzini, D., Kajba, D., Belletti, P. (2008). Genetic characterization of common ash (Fraxinus excelsior L.) populations in Bosnia and Herzegovina. Periodicum Biologorum, 110 (4), 323-328.

Brachet, S., Jubier, M. F., Richard, M., Jung-Muller, B., Frascaria-Lacoste, N. (1999). Rapid identification of microsatellite loci using 5' anchored PCR in the common ash Fraxinus excelsior. Mol. Ecol., 8, 160-163.
Chapuis, M. P., Estoup, A. (2007). Microsatellite null alleles and estimation of population differentiation. Mol. Biol. Evol., 24 (3), 621-631.

Dambis, J., Zilgalvis, J., Muceniece, A. (2007). Vēsturiskie dārzi un parki [Historical Gardens and Parks]. Valsts Kultūras pieminekḷu aizsardzības inspekcija, Rīga. 143 lpp. (in Latvian)

Dobrowolska, D., Hein, S., Oosterbaan, A., Wagner, S., Clark, J., Skovsgaard, J. P. (2011). A review of European ash (Fraxinus excelsior L.): Implications for silviculture. Forestry, 84 (2), 133-148.

Earl, D. A., vonHoldt, B. M. (2012). STRUCTURE HARVESTER: a website and program for visualizing STRUCTURE output and implementing the Evanno method. Conserv. Gen. Res., 4 (2), 359-361.

Evanno, G., Regnaut, S., Goudet, J. (2005). Detecting the number of clusters of individuals using the software STRUCTURE: A simulation study. Mol. Ecol., 14 (8), 2611-2620.

Ferrazzini, D., Monteleone, I., Belletti, P. (2007). Genetic variability and divergence among Italian populations of common ash (Fraxinus excelsior L.). Ann. For. Sci., 64 (2), 159-168.

Goudet, J. (2001). FSTAT, a program to estimate and test gene diversities and fixation indices (version 2.9.3). Available at:

http://www.unil.ch/izea/softwares/fstat.html (accessed 11.11.2015).

Hebel, I., Haas, R., Dounavi, A. (2006). Genetic variation of common ash (Fraxinus excelsior L.) populations from provenance regions in southern Germany by using nuclear and chloroplast microsatellites. Silvae Genetica, 55 (1), 38-43.

Heuertz, M., Hausman, J. F., Tsvetkov, I., Frascaria-Lacoste, N., Vekemans, X. (2001). Assessment of genetic structure within and among Bulgarian populations of the common ash (Fraxinus excelsior L.). Mol. Ecol., 10 (7), 1615-1623.

Heuertz, M., Vekemans, X., Hausman, J. F., Palada, M., Hardy, O. J. (2003). Estimating seed vs. pollen dispersal from spatial genetic structure in the common ash. Mol. Ecol., 12 (9), 2483-2495.

Heuertz, M., Hausman, J. F., Hardy, O. J., Vendramin, G. G., FrascariaLacoste, N., Vekemans, X. (2004a). Nuclear microsatellites reveal contrasting patterns of genetic structure between western and southeastern European populations of the common ash (Fraxinus excelsior L.). Evolution, 58 (5), 976-988.

Heuertz, M., Fineschi, S., Anzidei, M., Pastorelli, R., Salvini, D., Paule, L., Frascaria-Lacoste, N. Hardy, O.J., Vekemans, X., Vendramin, G. G. (2004b). Chloroplast DNA variation and postglacial recolonization of common ash (Fraxinus excelsior L.) in Europe. Mol. Ecol., 13 (11), 3437-3452.

Kowalski, T., (2006). Chalara fraxinea sp nov. associated with dieback of ash (Fraxinus excelsior) in Poland. For. Pathol., 36, 264-270.

Kowalski, T., Holdenrieder, O., (2009). Pathogenicity of Chalara fraxinea. For. Pathol., 39, 1-7.

Kupcis, J., Lībietis, J. (1933/34). Kemeri. In: Latviešu Konversācijas Vārdnīca. 10. sēj. [Latvian Encyclopaedia. Vol. 10]. Švābe, A. (ed.). Rīga, 19411-19428 (in Latvian).

Laiviňš, M., Mangale, D. (2004). Parastā oša (Fraxinus excelsior) paaugas izplatība Latvijā [The distribution of young growth of the common ash ( $F$. excelsior) in Latvia]. Mežzinātne, 13 (46), 61-69 (in Latvian).

Lefort, F., Brachet, S., Frascaria-Lacoste, N., Edwards, K. J., Douglas, G. C. (1999). Identification and characterisation of microsatellite loci in ash (Fraxinus excelsior L.) and their conservation in the olive family (Oleaceae). Mol. Ecol., 8, 1088-1091.

Morand, M. E., Brachet, S., Rossignol, P., Dufour, J., Frascaria-Lacoste, N. (2002). A generalized heterozygote deficiency assessed with microsatellites in French common ash populations. Mol. Ecol., 11 (3), 377-385.

Pasqualotto, A. C., Denning, D. W., Anderson, M. J. (2007). A cautionary tale: Lack of consistency in allele sizes between two laboratories for a published multilocus microsatellite typing system. J. Clin. Microbiol., 45 (2), 522-528. 
Pautasso, M., Aas, G., Queloz, V., Holdenrieder, O. (2013). European ash (Fraxinus excelsior) dieback - a conservation biology challenge. Biol. Conserv., 158, 37-49.

Peakall, R., Smouse, P. E. (2012). GenAlEx 6.5: Genetic analysis in Excel. Population genetic software for teaching and research-an update. Bioinformatics, 28, 2537-2539.

Pritchard, J. K., Stephens, M., Donnelly, P. (2000). Inference of population structure using multilocus genotype data. Genetics, 155 (2), 945-959.

Pliura, A., Lygis, V., Suchockas, V., Bartkevicius, E. (2011). Performance of twenty four European Fraxinus excelsior populations in three Lithuanian

Received 12 January 2016 progeny trials with a special emphasis on resistance to Chalara fraxinea. Baltic For., 17 (1), 17-34.

Tamura, K., Peterson, D., Peterson, N., Stecher, G., Nei, M., Kumar, S. (2011). MEGA5: molecular evolutionary genetics analysis using maximum likelihood, evolutionary distance, and maximum parsimony methods. Mol. Biol. Evol., 28 (10), 2731-2739.

Wallander, E., (2008). Systematics of Fraxinus (Oleaceae) and evolution of dioecy. Plant Syst. Evol., 273, 25-49.

Wagner, C. H. (1822). Preis-Courant derjenigen Gemüse-, Blumen-, Bäume-, und Sträucher-Samen bei C. H. Wagner. Riga, 2 s. (in German).

Zigra, J. H. (1805). Verzeichnis derjenigen exotischen Pflanzen, Bäume, Sträucher, welche in der Gartenhandlungen J. H. Zigra zu Riga. Gedruckt bei Wilchelm Ferdinand Häcker, Riga. 42 s. (in German).

\section{LATVIJAS OŠU (FRAXINUS EXCELSIOR L.) AUDŽU ĢENĒTISKĀS DAUDZVEIDĪBAS UN POPULĀCIJAS STRUKTŪRAS ANALĪZE, IZMANTOJOT KODOLA UN HLOROPLASTU SSR MARĶIERUS}

Parastais osis (Fraxinus excelsior L.) ir plaši izplatīts Eiropā. Latvija ir ošu izplatības areāla ziemelos. Eiropā novērojama ošu audžu masveida atmiršana, ko izraisa patogēnā sēne askomicēte Hymenoscyphus fraxineus. Ošu ǵenētiskās daudzveidības un populāciju struktūru izpētei Eiropas līmenī, kā arī tās atsevišḳos reǵionos, ir izmantoti hloroplastu un kodola DNS markieri. Darbā izmantotie markieri ar tiem vismaz dạ̦ēji sakrīt, dodot iespēju salīdzināt Latvijas un citus Eiropas reǵionu ošu audžu ǵenētiskos parametrus. Ar hloroplastu marķieriem veiktās analīzes Latvijas audzēs uzrādīja tikai vienu dominējošo haplotipu, kas sakrita ar Austrumeiropas un Skandināvijas haplotipu. Savukārt visos Ķemeru audzes indivīdos atrasts Centrāleiropas haplotips, kas norāda, ka šì audze dabīgi izveidojusies no blakus esošajā parkā introducētajiem ošiem. Kodola SSR markiieri uzrādīja zemu Latvijas ošu audžu diferenciāciju, kas, iespējams, ir saistīts ar efektīvu putekšn,u plūsmu starp audzēm. Gan ar hloroplastu, gan kodola DNS markieriem veiktās analīzes atklāj dažādus Latvijas ošu populāciju struktūras un izcelsmes aspektus. 